\title{
Одномоментна двобічна резекція легень з приводу туберкульозу
}

\author{
I. В. Корпусенко ${ }^{1}$ Ю. Ф. Савенков ${ }^{2}$ \\ ${ }^{1}$ Дніпропетровська медична академія МОЗ України, \\ ²Діпропетровське обласне клінічно-лікувальне об'єднання «Фтизіатрія» Дніпропетровської обласної ради

\section{One-staged bilateral pulmonary resection for tuberculosis}

\author{
I. V. Korpusenko', Yu. F. Savenkov ${ }^{2}$ \\ ${ }^{1}$ Dnipropetrovsk Medical Academy, Dnipro, \\ ${ }^{2}$ Dnipropetrovsk Regional Clinic-Treatment Complex «Phthisiatry» of the Dnipropetrovsk Region, Dnipro
}

\begin{abstract}
Реферат
Мета. Підвищення ефективності хірургічного лікування двобічного туберкульозу легень.

Матерали і методи. Проаналізовані результати оперативного лікування 53 хворих 3 приводу двобічного туберкульозу легень. У 28 з них виконано відеоасистовану торакоскопічну (ВАТС) одномоментну двобічну резекцію легень (основна група), у 25 - двобічну резекцію легень з використанням трансстернального доступу (група порівняння). Результати. При збільшенні операційного доступу збільшувався об'єм крововтрати. Відзначений позитивний, достовірний кореляційний зв'язок між величиною крововтрати й об'ємом ексудації в 1-шу добу після операції. За даними вивчення показників функції зовнішнього дихання (ФЗД) через 2 міс після операції у хворих обох груп виявлене помірне порушення біомеханіки дихання за типом ізольованої обструкції периферійних дихальних шляхів, зменшення співвідношення та життєвої ємності легень (ЖЄЛ) об'єму форсованого видиху за 1-шу секунду (ОФЛ $)_{1}$ внаслідок зменшення обсягу легеневої тканини. Бронхіальна прохідність на рівні максимальної об'ємної швидкості $\left(\mathrm{MOШ}_{25}\right)$ не порушена. Повне відновлення показників ФЗД відзначене тільки в основній групі.

Висновки. Застосування ВАТС резекції легень дозволило зменшити травматичність оперативного втручання, вираженість розладів ФЗД, крововтрату - в 1,5 раза, частоту післяопераційних ускладнень в 1,6 раза.

Ключові слова: туберкульоз легень; одномоментна двобічна резекція легень; мініторакотомія з відеопідтримкою. Abstract

Objective: enhancement of efficacy of surgical treatment of bilateral pulmonary tuberculosis.

Materials and methods. Results of operative treatment of 53 patients, suffering bilateral pulmonary tuberculosis, were analyzed. In 28 of them videoassisted thoracoscopic one-staged bilateral pulmonary resection (the main group), and in $25-$ bilateral pulmonary resection, using transsternal access (comparison group), were done.

Results. While enhancement of operative access the blood loss have increased also. Positive trustworthy correlational connection between value of the blood loss and volume of exudation on the first day postoperatively was noted. In accordance to the data of studying of the external respiratory function indices in 2 mo postoperatively in patients of both groups a moderate disorder of the respiration biomechanics in accordance to type of isolated obstruction of peripheral respiratory ways, reduction of ratio and pulmonary vital capacity of the forced expiration volume during first second due to reduction of the pulmonary tissue volume were revealed. Bronchial passability on the level of maximal volume velocity was not changed. Total restoration of the external respiration function was noted in the main group only.

Conclusion. Application of video-assisted thoracoscopic pulmonary resection have permitted to reduce traumatism of the operative intervention, severity of the external respiratory function disorders, the blood loss - in 1,5 times, the rate of postoperative morbidity in 1,6 times.

Keywords: pulmonary tuberculosis; one-staged bilateral pulmonary resection; minithoracotomy with videoassistance.
\end{abstract}

Незважаючи на певну стабілізацію показників захворюваності, епідемічна ситуація з туберкульозу в Україні складна. Щороку виявляють понад 30000 хворих на туберкульоз легень. Ефективність консервативного лікування не перевищує 70\% [1 - 4]. Значно (на 45\%) збільшилася кількість хворих з двобічними формами туберкульозу легень порівняно з такою в доепідемічному періоді $[5,6]$. Найбільш поширеним з приводу симетричного обмеженого процесу є виконання одномоментної двобічної резекції легень з використанням трансстернального доступу $[7,8]$. Проте застосування стернотомії супроводжується досить високою (13,5\%) частотою післяопераційних ускладнень і летальністю (3,6 - 4,7\%), пов'язаних із самим доступом [7, 9]. Пошук більш ефективних і менш травматичних методів лікування хворих з приво- ду двобічних обмежених форм туберкульозу легень є актуальною проблемою торакальної хірургії $[2,10]$.

Мета дослідження: підвищення ефективності хірургічного лікування двобічного туберкульозу легень.

\section{Матеріали і методи дослідження}

У торакальному відділенні в період з 2008 по 2016 р. оперовані 53 хворих з приводу обмежених форм туберкульозу легень, у 28 з них виконана ВАТС одночасна двобічна резекція легень (основна група), у 25 - одночасна двобічна резекція легень з використанням трансстернального доступу (група порівняння).

Обмеженим, як і більшість авторів, вважаємо сумарний обсяг деструктивного або казеозно-вогнищевого ураження не більше 5 сегментів з одного боку. Таким чи- 
ном, найбільш поширеною локалізацією деструктивного або казеозно-некротичного ураження легень, за якої показане хірургічне втручання, були сегменти: $\mathrm{C}_{\mathrm{I}}, \mathrm{C}_{\mathrm{II}}-$ $\mathrm{C}_{\mathrm{I}+\mathrm{II}}, \mathrm{C}_{\mathrm{I}-\mathrm{III}},-\mathrm{C}_{\mathrm{I}+\mathrm{II}}, \mathrm{C}_{\mathrm{VI}}-\mathrm{C}_{\mathrm{I}+\mathrm{II}}, \mathrm{C}_{\mathrm{VI}}, \mathrm{C}_{\mathrm{VI}}-\mathrm{C}_{\mathrm{X}}$. Виконувати одночасну двобічну резекцію легень у цих хворих дозволяли також задовільні функціональні показники ФЗД на рівні 65 - 80\% форсованої ЖЕЛ (ФЖЕЛ) і 65 - 70\% - хвилинної вентиляції легень (індекс вентиляції I - II ступеня).

В основній групі чоловіків було 26 (92,7\%), жінок - 2 (7,3\%), вік хворих від 28 до 42 років. 3 приводу двобічної солітарної туберкуломи легень оперовані 14 (50\%) хворих, множинних туберкулом - 8 (28,6\%), кавернозного процесу - 6 (21,4\%). Тобто, 84,6\% пацієнтів цієї групи оперовані з приводу обмежених казеозних утворень легень (рис. 1). В усіх хворих загальний обсяг ураження не перевищував 5 сегментів. Оперовані з приводу обмеженого казеозно-некротичного ураження верхівкових та верхівково-задніх сегментів 83,3\% хворих, ураження $\mathrm{C}_{\mathrm{VI}}$ або $\mathrm{C}_{\mathrm{vI}}-\mathrm{C}_{\mathrm{x}}-16,7 \%$.

При верхівковій або верхівково-задній локалізації туберкульозного ураження операцію виконували в напівбічному положенні хворого на операційному столі, здійснювали аксилярну торакотомію (довжина розрізу 6 см - мініторакотомія) через четверте міжребер'я без ушкодження великого грудного м'яза - (m. pectoralis major) та найширшого м'яза спини (m. latissimus dorsi). Додатково у третьому міжребер”ї по передній пахвовій лінії встановлювали торакопорт діаметром 10 мм для введення відеокамери.

У 72,7\% хворих за наявності виражених інтраплевральних спайок використовували ранорозширювач, у решти - всі інструменти вводили в плевральну порожнину через мініторакотомний доступ. Інтраплевральні спайки не виявлені у 27,3\% пацієнтів, у 29,4\% - поодинокі спайки, у 32,4\% - займали всю верхню частину плевральної порожнини, у 10,9\% - до 50\% плевральної порожнини. Після виділення легені із спайок проводили іiі пальпацію, для чого окремі частини легені підводили до

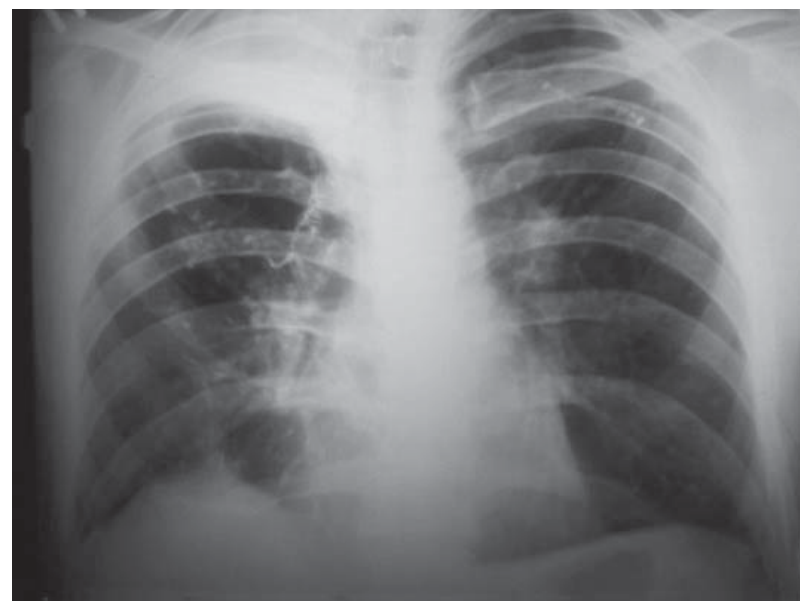

Puc. 1.

Оглядова рентгенографія хворого Л. до операції. У правій легені в $C_{I I}$ сегменті овальної форми інтенсивна тінь розмірами 6,0 × 3,7 cм, поліморфні вогнища в ділянщі верхівки. Улівій легені в $C_{I+I I}$ сегменті туберкулома розмірами 3,5 × 2,5 см, з чіткими контурами, виявлені порожнини розпаду та дрібні щільні вогнища. торакотомної рани вікончастим затискачем. Особливу увагу приділяли оцінюванню стану легеневої тканини по лінії передбачуваної резекції. Резекцію легені здійснювали за допомогою зшивальних апаратів TLH-30, TLH-60, УO-40, Eshelon-60. У хворих при локалізації туберкулом в $\mathrm{C}_{\mathrm{VI}}, \mathrm{C}_{\mathrm{x}}$ сегментах мініторакотомію здійснювали в аускультативному трикутнику, обмеженому зверху трапецієподібним м'язом (m. trapezius), знизу - найширшим м'язом спини (m. latissimus dorsi) через шосте або сьоме міжребер'я в положенні хворого лежачи на животі. Відеокамеру вводили на одне міжребер'я вище через окремий торакопорт. Поліспастичний шов на ребра не накладали. Плевральну порожнину дренували однією трубкою.

У групі порівняння чоловіків було 20 (80\%), жінок - 5 (20\%), вік хворих від 21 до 50 років. Солітарні або множинні туберкуломи виявлені у 22 (88\%) пацієнтів, конгломерат казеозно-некротичних вогнищ - у 2 (8\%), двобічне кавернозне ураження - в 1 (4\%). За даними функціонального обстеження, у 23 (92\%) хворих встановлена дихальна недостатність І стадії, у 2 (8\%) - ІІ стадії.

Одночасна двобічна сегментарна резекція із сумарним обсягом до 4 сегментів виконана у 22 (88\%) хворих, одномоментна резекція від 4 до 5 сегментів (лобектомія, сегментарна резекція другої легені) - у 3 (12\%). Після розсічення груднини іiі фрагменти розводили на відстань 10 - 12 см. Після оголення переднього середостіння мобілізували обидва плевральні мішки. 3 приводу симетричних, обмежених 2 - 3 сегментами процесів, першою виконували резекцію на боці менш виражених плевральних спайок, що дозволяло зменшити інтраопераційну крововтрату. При значній різниці тяжкості патологічного процесу в обох легенях спочатку здійснювали резекцію легені, в якій процес більш активний. Після завершення повного пневмолізу виконували резекцію легені, як правило, з використанням апаратного методу.

До і після операції проводили спірографію з використанням системи «Спірографія». Рентгенологічне до-

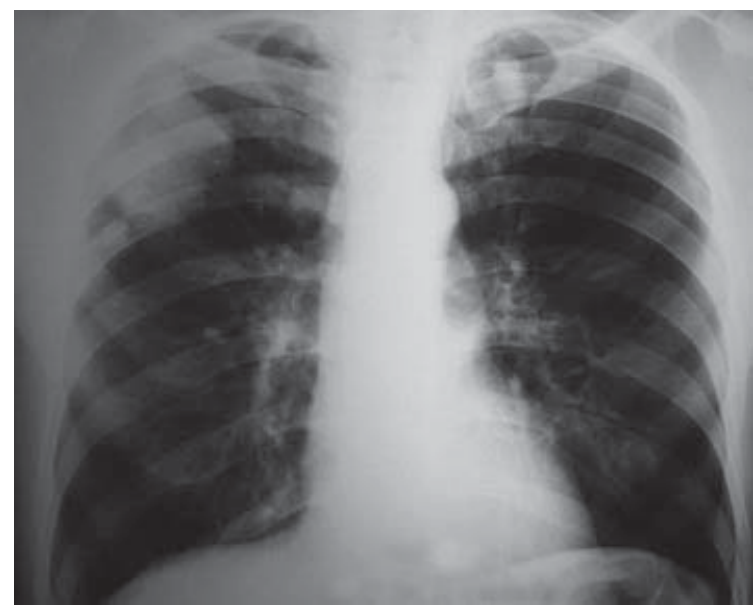

Puc.2.

Рентгенографія через 30 діб.

Уверхнъомедіальному відділі правої легені в металевий шов, потовщення міжчасткової плеври, плевро-діафрагмальні спайки.

у лівійлегені на рівні периого міжребер'я ланщюг металевих швів, потовщення апікальної плеври. 
слідження проводили до і після операції на установці «MtaERCURY - 332», здійснювали багатоосьову рентгеноскопію, рентгенографію та лінійну томографію органів грудної клітки.

Статистична обробка проведена за допомогою програмного продукту Statistica 6.1.

\section{Результати}

При виконанні ВАТС одночасної двобічної резекції легень ускладнень не було, не виникло технічних труднощів, що потребувало б конверсії (рис. 2).

Після операції ускладнення виникли у 6 (24,0\%) хворих групи порівняння (табл. 1).

Помер 1 (4\%) хворий після двобічної бісегментарної резекції, виконаної з приводу двобічного кавернозного туберкульозу з бактеріовиділенням.

При аналізі взаємозв'язку тривалості операції та виду хірургічного доступу достовірної різниці не було (р $>0,05)$.

Об'єм інтраопераційної крововтрати в основній групі в 1,5 раза менший, ніж у групі порівняння ( $<<0,001)$.

На підставі даних кореляційного аналізу доведено, що при збільшенні розмірів операційного доступу збільшується об'єм крововтрати під час операції (r=0,62, p < 0,001). Встановлений також позитивний, достовірний, середньої сили кореляційний зв'язок між величиною крововтрати і об'ємом ексудації в 1-шу добу після операції (r=0,48, $\mathrm{p}<0,001)$.

При аналізі факторів, пов'язаних зі збільшенням ексудації, відзначений їх безпосередній зв'язок з травматич- ністю оперативного втручання: при виконанні мініторакотомії менший розтин міжребрових м'язів порівняно 3 таким за стандартної торакотомії, проте, ушкоджується реброва частина пристінкової плеври, що є основним джерелом післяопераційної ексудації.

При застосуванні трансстернального доступу, навпаки, не травмується міжребер'я, проте розсікають середостінну частину пристінкової плеври.

Тривалість лікування у стаціонарі хворих основної групи достовірно менша відносно такої в групі порівняння $(\mathrm{p}<0,05)$.

У пацієнтів основної групи частота післяопераційних ускладнень в 1,6 раза менша, ніж у хворих групи порівняння ( $<<0,001)$.

Після операції всі пацієнти основної групи живі, в групі порівняння помер 1 (4\%) хворий від гострої дихальної недостатності.

Вивчено динаміку змін показників вентиляційної функції легень залежно від способу їх резекції (табл. 2).

Через 1 міс після операції в усіх хворих спостерігали погіршення показників ФЗД на 27,5 - 55\%, ступінь якого був різним. Так, ФЖЕЛ в основній групі знижувалась значно менше, ніж у групі порівняння (p < 0,05). Наявність достовірних розбіжностей $(\mathrm{p}<0,05)$ за показником МОШ $_{25}$ у двох групах хворих свідчила про його зв'язок зі способом хірургічного доступу під час резекції легень.

У хворих групи порівняння констатовано значно вираженіше погіршення показників еластичних властивостей легень, ознак респіраторної вентиляційної недо-

\begin{tabular}{|c|c|c|}
\hline \multirow{2}{*}{ Критерії оцінки } & \multicolumn{2}{|c|}{ Величина показника в групах $(\bar{x} \pm m)$} \\
\hline & порівняння $(n=25)$ & основної $(n=28)$ \\
\hline Тривалість операції, год & $2,05 \pm 0,21$ & $1,90 \pm 0,12$ \\
\hline Інтраопераційна крововтрата, мл & $372 \pm 2,50$ & $234 \pm 5,20^{*}$ \\
\hline Кількість ексудату за першу добу, мл & $363 \pm 3,40$ & $286 \pm 6,10^{*}$ \\
\hline Тривалість ексудації, діб & $2,20 \pm 0,45$ & $1,00 \pm 0,07^{*}$ \\
\hline Частота післяопераційних ускладнень, \% & $24,0 \pm 1,40$ & $12,50 \pm 0,13^{\Delta}$ \\
\hline Післяопераційна дихальна недостатність, \% & $4,20 \pm 0,17$ & - \\
\hline Післяопераційна летальність, \% & $4,0 \pm 0,12$ & - \\
\hline Середня тривалість застосування наркотичних аналгетиків, діб & $4,30 \pm 0,46$ & $3,80 \pm 0,43$ \\
\hline Середня тривалість лікування після операції, днів & $60,40 \pm 2,06$ & $52,40 \pm 2,63$ \\
\hline Підсумкова клінічна ефективність, \% & $78,40 \pm 2,30$ & $97,30 \pm 4,09$ \\
\hline
\end{tabular}

\begin{tabular}{|c|c|c|c|c|c|c|}
\hline \multirow{3}{*}{ Показники ФЗД } & \multicolumn{6}{|c|}{ Величина показника, \% від належного в групах ( $\bar{x} \pm m)$} \\
\hline & \multicolumn{3}{|c|}{ основній $(n=28)$} & \multicolumn{3}{|c|}{ порівняння (n=25) } \\
\hline & до операції & через 1 міс & через 2 міс & до операції & через 1 міс & через 2 міс \\
\hline ФЖЕЛ & $90,6 \pm 2,8$ & $76,4 \pm 2,4^{* \Delta}$ & $90,1 \pm 3,1$ & $91,2 \pm 1,8$ & $68,7 \pm 5,6$ & $91,9 \pm 1,9$ \\
\hline $\mathrm{O} Ф \mathrm{~B}_{1}$ & $93,2 \pm 1,8$ & $88,4 \pm 2,7$ & $91,7 \pm 1,6$ & $92 \pm 2,4$ & $81,8 \pm 3,1$ & $92,3 \pm 2,4$ \\
\hline ОФВ $1 /$ ЖЕЛ & $98,4 \pm 3,1$ & $76,6 \pm 2,8^{* \Delta}$ & $97,7 \pm 4,1$ & $106 \pm 4,6$ & $65,7 \pm 2,7$ & $95,4 \pm 3,8$ \\
\hline пош & $100,7 \pm 4,1$ & $74,2 \pm 2,1^{* \Delta}$ & $99,2 \pm 1,7$ & $101 \pm 2,3$ & $56,2 \pm 3,8$ & $100,2 \pm 1,2$ \\
\hline МOШ $_{75}$ & $103,7 \pm 2,1$ & $94,2 \pm 1,8^{* \Delta}$ & $101,2 \pm 2,5$ & $107,2 \pm 4,3$ & $93,8 \pm 1,4$ & $106,2 \pm 4,1$ \\
\hline МОШ & $106,8 \pm 2,4$ & $97,2 \pm 4,1$ & $103,8 \pm 2,7$ & $110,1 \pm 4,6$ & $97,6 \pm 3,5$ & $107,3 \pm 3,5$ \\
\hline МOШ $_{25}$ & $102,4 \pm 2,2$ & $96,7 \pm 5,1$ & $100,7 \pm 4,2$ & $101,1 \pm 5,0$ & $93,5 \pm 1,8$ & $102,1 \pm 5,2$ \\
\hline
\end{tabular}


статності, зменшення максимальної швидкості форсованого видиху на рівні дрібних бронхів $\left(\right.$ МОШ $\left._{75}\right)$, пікова об'ємна швидкість форсованого видиху ПОШ та МОШ зменшувались у середньому на 28 - 45\%; у хворих основної групи ці показники коливались значно меншою мірою.

Через 2 міс після операції у хворих обох груп виявлене помірне порушення біомеханіки дихання за типом ізольованої обструкції периферійного відділу дихальних шляхів, зменшення співвідношення ОФВ $/$ ЖЕЛ унаслідок зменшення обсягу легеневої тканини. Прохідність бронхів на рівні МОШ $_{25}$ не порушена. Проте майже повне відновлення показників ФЗД відзначали тільки у пацієнтів основної групи.

\section{Обговорення}

У літературі нами знайдено лише кілька публікацій, присвячених застосуванню одномоментної двобічної ВАТС-резекції легень при туберкульозі. Так, автори наводять дані про виконання відеоторакоскопічної та ВАТС - резекції з приводу двобічної туберкуломи у 32 хворих [10] та одномоментної двобічної резекції легенів з використанням мініінвазивних доступів [8].

За нашими даними, при застосуванні трансстернального доступу під час виконання одночасної двобічної резекції легень у 7\% хворих виникли ускладнення, пов'язані із самим доступом: остеоміеліт груднини, передній гнійний медіастиніт, гнійний перикардит, розходження фрагментів груднини. На нашу думку, резекція лівої легені, зокрема сегментектомія $\mathrm{C}_{\mathrm{VI}}$ з використанням трансстернального доступу, технічно вкрай складна, особливо при вираженому рубцево-спайковому процесі в плевральній порожнині. Застосування трансстернального доступу не забезпечує зниження ризику виникнення легеневої недостатності після операції, що у 12,5\% хворих потребувало проведення пролонгованої штучної вентиляції легень. Єдиною перевагою стернотомії при одночасній двобічній резекції легені $є$ можливість оперувати в один етап. Проте об'єднати дві окремі операції в одне, зберігаючи при цьому принцип послідовності втручання на обох легенях, можливо при застосуванні й менш травматичних, мініінвазивних доступів, які також дозволяють уникнути травми дихальних м'язів, міжребрових судин та нервів.

Наші дані підтверджують результати інших авторів щодо безсумнівних переваг одномоментної двобічної резекції легень за принципом ВАТС-резекції порівняно iз трансстернальним доступом. Техніка відеоасистованої резекції легені з приводу туберкульозу краще, оскільки дозволяє візуально й пальпаторно оцінити передба- чувану лінію резекції легені, виконати типову сегментектомію, нівелювати ризик накладення швів на рентгенонегативне вогнище та виникнення гострої дихальної або легенево-серцевої недостатності.

\section{Висновки}

1. Застосування ВАТС одночасної двобічної резекції легень у хворих з приводу двобічного туберкульозу дозволяє значно зменшити травматичність оперативного втручання, що сприяє менш вираженому порушенню ФЗД, зменшенню тяжкості больового синдрому після операції внаслідок мініінвазивності.

2. Використання ВАТС дозволяє краще оглянути зону резекції легені завдяки оптичному збільшенню, радикально видалити патологічне вогнище, в 1,5 раза зменшити крововтрату, в 1,6 раза - частоту післяопераційних ускладнень порівняно з такими при застосуванні стернотомного доступу.

\section{References}

1. Melnik VM, Novozhilova IO, Matusevich VG, Prikhodko AM. The effectiveness of treatment of patients with multidrug-resistant tuberculosis in Ukraine. Analysis of official statements. Ukr pulmonol zhurnal. 2014;(2):36-9. [In Ukrainian].

2. Kilani T, Boudaya MS, Zribi H. Surgery for thoracic tuberculosis. Rev Pneumol Clin. 2015;(2-3):140-158. doi: 10.1016/j.pneumo.2014.03.005

3. Madansein R, Parida S, Padayatchi N. Surgical treatment of complications of pulmonary tuberculosis, including drug-resistant tuberculosis. Int J Infect Dis. 2015;(3):61-7. doi: 10.1016/j.ijid.2015.01.019.

4. Roberts-Witteveen A, Reinten T, Christensen A, Sintchenko V, Seale P, Lowbridge C. Multidrug-resistant tuberculosis in New South Wales, Australia, 1999-2010: a case series report. Int J Tuberc Lung Dis. 2015 Jul;19(7):850-6. doi: 10.5588/ijtld.14.0575.

5. Duzhiy ID, Kravets OV. To surgical treatment regarding widespread drug-resistant pulmonary tuberculosis. Ukr pulmonol zhurnal. 2014;(1):39. [In Ukrainian].

6. Obremskaya OK, Opanasenko NS, Klimets EV. Features of preoperative preparation and postoperative management of pulmonary and fisiopatolygica patients with comorbidity. Ibid:57-8. [In Russian].

7. Ivanov AV, Svintsov AE, Mokhirev AI. Simultaneous bilateral resection of the lungs from one-sided intercostal-mediastinal access in patients with tuberculosis. Tuberkulez v Rossii. Materialy VIII Ros. s"ezda ftiziatrov. Moskva; 2007:468-9. [In Russian].

8. Porkhanov VA, Marchenko LG, Polyakov IS. Surgical treatment of bilateral pulmonary tuberculosis. Problemy tuberkuleza. 2002;(4):22-5. [In Russian].

9. Abbo O, Guatta R, Pinnagoda K. Bilateral anterior sternothoracotomy (clamshell incision): a suitable alternative for bilateral lung sarcoma metastasis in children. World J Surg Oncol. 2014;(12):144-9. doi. org/10.1186/1477-7819-12-233

10. Giller DB, Tokaev KV, Bagirov MA. Immediate results of videotorakoscopic and video-aspiratorocoscopic resections of the lungs and pneumonectomies in patients with pulmonary tuberculosis. Problemy tuberkuleza. 2006;(8):38-42. [In Russian]. 